\title{
Using Technology in Education from the Pre-service Science and Mathematics Teachers' Perspectives
}

\author{
Asli Saylan ${ }^{1}$, Nagihan Tanik Onal ${ }^{1} \&$ Nezih Onal ${ }^{2}$ \\ ${ }^{1}$ Faculty of Education, Erciyes University, Kayseri, Turkey \\ ${ }^{2}$ Faculty of Education, Nigde Omer Halisdemir University, Nigde, Turkey \\ Correspondence: Asli Saylan, Faculty of Education, Erciyes University, Kayseri, Turkey. Tel: \\ 352-207-6666/37103. E-mail: aslisaylan@erciyes.edu.tr
}

Received: June 6, $2018 \quad$ Accepted: July 15, $2018 \quad$ Online Published: September 27, 2018

doi:10.5539/ies.v11n10p28 URL: https://doi.org/10.5539/ies.v11n10p28

\begin{abstract}
The purpose of this study is to find out pre-service teachers' views about the use of technology in science and middle school mathematics courses. For this purpose, semi-structured interviews were conducted with 30 pre-service teachers studying in a university in Central Anatolia Region during the spring semester of 2017-2018 academic year. The obtained data were analyzed using content analysis by the researchers. According to the findings, pre-service teachers thought that computer, smart board, projector, laboratory equipment, notebook, and pencil are the main technologies that can be used in the classroom. The participants also thought that presentation and video processing programs make course interesting and enjoyable, visualize the topic, make learning easier, and enable the permanent learning. However, they also stated that preparing a presentation and video processing program may be time consuming and boring if it is used throughout the course; and the program may not be useful for every subject. The participants found blogs and web pages useful since they give opportunities to share course content, materials, and information, make announcements to make students prepared for the course. Almost all the participants believed that technological equipment of their classroom definitely affect their teaching. Namely, in an ill-equipped class, the students would have difficulty in learning, tend to memorize things; also their attitudes, interests, and motivations towards the course, and participation in the lesson would be affected; and their learning would not be permanent.
\end{abstract}

Keywords: mathematics, phenomenology, pre-service teacher, science, use of technology in education

\section{Introduction}

In today's information and technology age, the developments in science and technology change our understanding of the world by affecting us in areas such as communication, agriculture, health, safety, and transportation. As we move into a technology-based society, the role of technology in education is becoming a globally important concern and a great amount of investment and research in the field of educational technologies has been made throughout the world. Turkish Ministry of National Education (MoNE) has also made a great effort and financial investments to implement technology into the classrooms. Being one of these investments, "the Movement to Enhance Opportunities and Improve Technology Project (the FATIH Project) aims to enable self-regulated, mobile, and ubiquitous learning via tablet computers, technology-rich classroom environments, and online digital sources for students (Yüksel-Arslan, Şad, \& Yıldırım, 2017). Consequently, it has been a requirement for teachers to use and implement technology into their classrooms.

For many years, researchers, educators, and policy-makers have been exploring the best ways to integrate technology in classrooms to enhance teaching and learning. The implementation of technology into teaching process is directly or indirectly affected by many dynamic variables such as students, teachers, administrators, and the availability of hardware and software tools (Ertmer, 2005). Undoubtedly, the teacher is the most important ingredient for using and integrating technology (Mandell, Sorge, \& Russell, 2002; Zhao, Hueyshan, \& Mishra, 2001). Effective use of technology in education can only be realized by equipped teachers in this regard (Özden, Çağıltay, \& Çağıltay, 2004). Without such teachers, students' exposure to technology remains limited and inequitable. Technology integration is not much about the availability of technology, but more about the teachers' effective use of technology that makes a difference in reforming the classroom (Gorder, 2008). Therefore, it is important to find out pre and in-service teachers' views regarding the use of technology in education. 
Educational technologies contribute to classroom efficiency by saving time (Çoklar \& Tercan, 2014), motivating learners (Ciampa, 2014; Roblyer \& Edwards, 2005), enhancing learning (Cope \& Ward, 2002; Hennessy, 2008; Woodard, 2003) and promoting academic achievement in courses such as math and science (Lewin, Somekh, \& Steadman, 2008).

There is a large amount of quantitative studies that conducted about the attitudes (Baturay, Gökçearslan, \& Ke, 2017; Metin, Birişçi, \& Coşkun, 2013; Teo, 2008), perceptions (Kağızmanl, Tatar, \& Zengin, 2013; Köksal \& Yaman, 2012), self-efficacy (Çelik \& Karamustafaoğlu, 2016), and technology competence of pre-service teachers (Baturay, Gökçearslan, \& Ke, 2017), while a limited amount of qualitative study was conducted about the pre-service teachers' views regarding using technology in education (İnel, Evrekli, \& Balım, 2011; Saraç \& Özarslan, 2017; Som, 2017).

Unfortunately, the technological tools are generally provided to teachers without considering their views on them. Since technology is closely related with science and mathematics (Mettas \& Constantinou, 2007), being future teachers, it is important to investigate the pre-service science and mathematics teachers' views regarding using technology in education. Hence, this study aims to investigate the views of pre-service science and mathematics teachers on using technology in education.

\subsection{Research Question}

The research question was determined as "What are the pre-service teachers' views about the use of technology in science and middle school mathematics courses?" The following sub-problems will be solved in the study:

i) What are the technologies that can be used in science / middle school mathematics courses?

ii) What are the participants' thoughts about using technology in science / middle school math course?

iii) What are the participants' thoughts about presentation programs that can be used in science / middle school math course?

iv) What are the participants' thoughts about using blog or web page in science / middle school math course?

v) What are the participants' thoughts about using video processing programs in science / middle school math course?

vi) What are the participants' thoughts about teaching science / middle school math that they will perform in technologically full or ill-equipped classrooms?

\section{Method}

\subsection{Research Design}

This research was conducted based on the phenomenological research design of the qualitative research approach. Phenomenology is a design that has strong philosophical foundations. In this design, the participants describe their experiences about a phenomenon (Creswell, 2013). The subjects of phenomenology are the feelings, perceptions, and thoughts concerning the participants' experiences (Van Manen, 2007). The research was carried out with phenomenology design since it was aimed to describe pre-service teachers' thoughts regarding the use of technology in science and mathematics education in detail. The research design is shown in Figure 1.

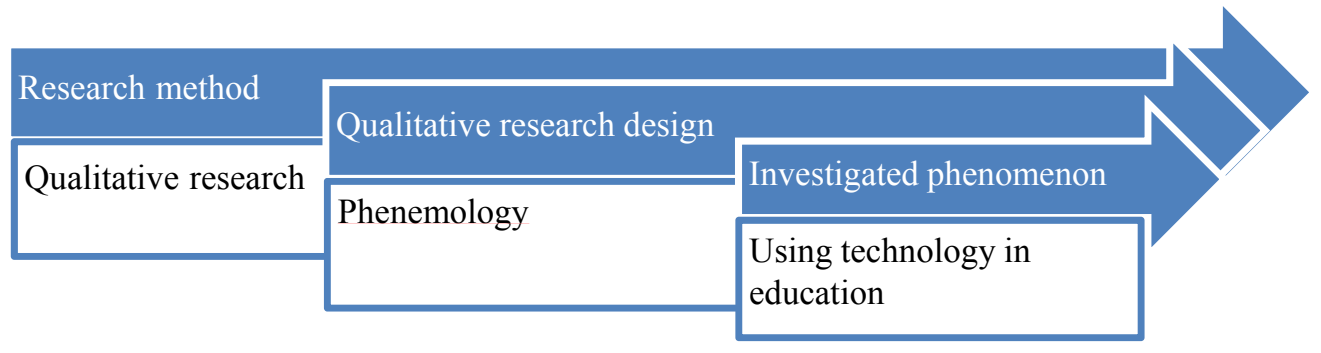

Figure 1. Research Design

\subsection{Participants}

In qualitative research, the researcher does not aim to make generalizations about the subject that s/he investigate. In this research paradigm, the researcher aims to collect detailed data on the participants. Therefore, in the 
phenomenological design of the qualitative research paradigm, it is suggested to use the criterion sampling from the purposive sampling methods. Because in phenomenological studies participants need to have experiences in the investigated phenomenon and be the individuals who reflect these experiences (Glesne, 2012). For this reason, in this study, participants were selected using criterion sampling, which is one of the purposive sampling methods (Figure 2). The purposive sampling method is a sampling method that primarily used in qualitative studies and leads to greater depth of information (Patton, 2002). Since the phenomenon that was investigated in this study is to determine pre-service science and middle school math teachers' thoughts about using technology in science and middle school math courses, pre-service science and middle school math teachers having experience in this topic were selected as participants in the research. In the study, predetermined criterion is that the participants must took and passed 'Technology Applications in Education' elective course as well as 'Computer I', 'Computer II', and 'Instructional Technologies and Material Design' must courses.

Within this context, the participants of the study are 30 junior pre-service teachers, 15 science, and 15 mathematics, during the spring semester of the 2017-2018 academic year.

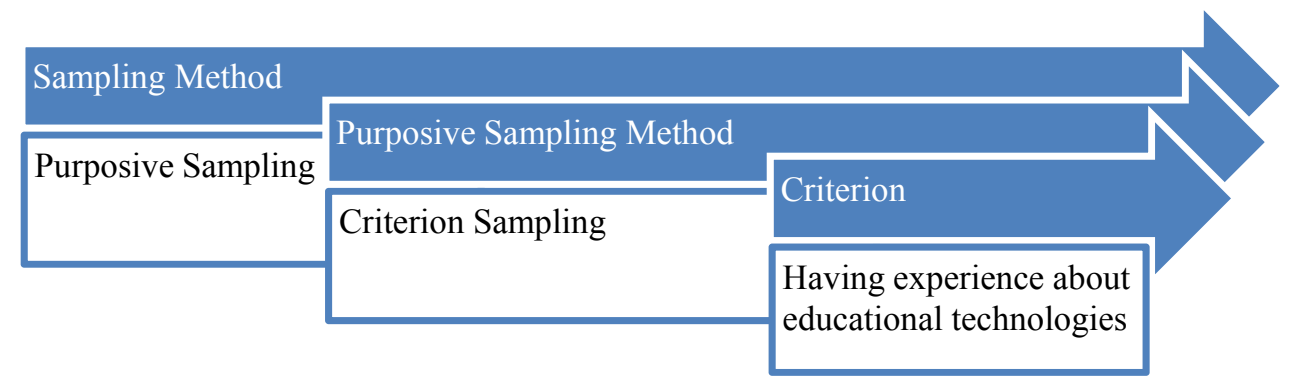

Figure 2. Participants of the study

\subsection{Instruments}

In a qualitative research, the main purpose of the interviews is to reveal knowledge, experience, feelings, thoughts, and perceptions of the interviewees about the research topic (Patton, 2002). Therefore, in this study, semi-structured interviews were conducted to collect data. Before the interviews, a semi-structured interview form with six open-ended questions was prepared to seek answers to the research questions. The form was examined and approved by three experts. In these interviews, the researcher is free to ask additional questions to obtain more detailed information about the topics, by remaining faithful to the pre-prepared questions (Yıldırım \& Şimşek, 2008). Expert opinion and inter-rater reliability were used to ensure validity and reliability of the interview form consisting of open-ended questions. The internal consistency coefficient of the instrument that was scored by two field experts was calculated as .93 .

\subsection{Data Collection}

Before the main study, the researchers conducted a pilot study with three pre-service teachers in order to gain experience, determine the required time for the interview, and to remove the possible problems that may arise during interviews. Since no problems were detected in the pilot studies, it was started to the main study without any change.

Semi-structured interviews were conducted face-to-face by one of the researchers. The interviews were conducted at times when the participants were appropriate, and in the place where nobody is around except the participant and researcher, and where every precaution was taken to ensure the reliability of the study. The interviews were completed within a three-week time period.

Researchers recorded the interviews with the participants' permission via voice recorder in order to prevent possible data loss and to take precautions against the threats of internal validity. At the same time, during the interviews, the researcher took notes of the participants' gestures and facial expressions. After the interviews were completed, the data obtained from the sound recordings were transcripted for analysis. 


\subsection{Data Analysis}

Before the data were analyzed, the necessary preparations had been made for the data obtained. Within this scope, first of all, the form applied to the participants was checked individually and numbers were given starting from 1 . In order to hide their names, pre-service science teacher participants were coded as S1, S2, .., S15; and; pre-service middle school mathematics teacher participants were coded as M1, M2, .., M15. Then, the interviews were listened by the researchers, verbatim transcription was made, and turned into a MS Word document. The interviews were transcripted within two weeks. The researchers carried out their analyzes through these texts. The data were analyzed using content analysis. It is aimed to reach concepts and relationships that can explain the collected data in content analysis. For this purpose, the collected data must be conceptualized, organized logically based on the emerging concepts, and the themes should be determined accordingly (Yıldırım \& Şimşek, 2008).

\subsubsection{Validity and Reliability}

The validity and reliability of a research are considered to be the most important criteria that demonstrate the credibility or quality of the findings (Daymon \& Holloway, 2003). For this reason, some precautions were taken to ensure validity and reliability of the research. Firstly, to provide internal validity, the semi-structured interview form constructed to collect data was presented to the expert opinion and the interviews were kept both in voice recorder and on the computer. Moreover, the attention has been paid to collect data and report each stage of the research process in detail. The findings obtained in the study were shared with the participants and they were asked whether they agree with the analysis results or not. Including direct quotations in the findings part is also among the precautions taken to enhance the internal validity. Moreover, whether the researchers and participants know each other for a while is also important for internal validity in terms of researcher-participant interaction. In order to enhance external validity; the research environment, characteristics of the participants, and data collection process were described in detail so that other researchers can design a different research by following these paths. In addition, the participants, that had been selected using purposeful sampling in order to enhance external validity, were introduced in detail in 'Participants' part. Preventing data loss by recording interviews with the voice recorder and avoiding bias in interpretation of the findings are the precautions for internal validity, whereas analyzing the data by two researchers to assess their consistency is the precaution for external validity.

\section{Results}

\subsection{Thoughts on the Technologies that can be used in Science/Middle School Math Courses}

When it was asked participants which educational technologies they could use in their lessons, the following findings were reached:

According to the pre-service science teachers; smart boards, laboratory equipment, computer, and projector are the foremost technologies that can be used in science lessons. Furthermore, overhead projector, tablet computers, mobile devices, animations, videos, posters, models, and telescope are also among the answers.

On the other side, according to the pre-service math teachers, smart boards, computer, notebook, and pencil are the foremost technologies that can be used in math lessons. All 15 of the pre-service mathematics teachers gave this answer. According to the participants, teaching mathematics can be done more effectively by using math-specific software, owing to the computer and smart board technologies. At the same time, participants thought that notebook and pencil are also always important in teaching mathematics. Moreover, pre-service math teachers thought that tablet computer and videos also can be used in teaching math. Figure 3 shows the educational technology tools that can be used by both groups of pre-service teachers in their lessons: 
Pre-service Science Teachers

- Smart board

- Laboratory equipment

- Computer

- Projector

- Overhead projector

- Tablet computers

- Mobile devices

-Animations, videos, posters, models, and telescope
Pre-service Middle School Mathematics Teachers
- Computer
- Smart board
- Notebook
-Pencil
- Tablet Computer
- Videos

Figure 3. Technologies that can be used in class according to the participants

When the opinions of the participants on the use of technology in education are examined, it was seen that both pre-service science and mathematics teachers find using technology in their lessons important. The participants justified their opinion as; using technology in education is a requirement to adapt to changing world conditions, technology provides permanent learning since it appeals to more than one sense, makes learning easier, arouses students' interest, embodies the abstract subjects and saves time.

When thoughts of the two groups are examined separately, in addition to the above-mentioned opinions, pre-service science teachers opinions on using technology in their courses was gathered under two themes as positive and negative opinions. Regarding the theme of positive opinions, the participants thought that the use of technology in their lessons is suitable for the students who have different learning styles; it facilitates access to information; increases learning motivation, creativity, and academic achievement. The thoughts of S2 and S8 in this theme are as follows, respectively:

"Because there are many abstract concepts in science, students have difficulty in understanding these concepts. The use of technology in science education makes learning easier for students since abstract subjects are embodied. These technologies are suitable for students who learn in different ways."

"It is much more effective to practice or watch videos about the lesson than to tell students that blue litmus paper turns red in acid. It is very effective to enable students to see the bacteria with their own eyes under the microscope. Using technology provides permanent learning. It embodies the knowledge."

On the other hand, the views under the negative opinions theme are mainly related to pre-service science teachers' using the mentioned technologies in their lessons lead to some problems. The participants have some negative opinions such as it makes students lazy, does not improve teaching skills, weakens the students' writing skills, increases students' addiction to the technology, and causes to lose attention. The participants also stated that not every school has the physical resources to reach these technologies at a certain cost, and if the electric power is cut off, or when there is a technical failure, the course may be interrupted. The participants S9 and S13, who commented on this theme, respectively stated that:

"Teachers need to know how to use technology. Otherwise, you cannot get efficiency even if you stock up technology in the classroom."

"Besides, students are always glued to their cell phone in daily life. In addition to this, if the technology is used frequently at the schools, students may be totally addicted to technology. It may make students lazy. We also do it, for example, we think that we have slides anyway and we do not listen to the teacher. Moreover, if a problem occurs in the tool, the course may be delayed."

The pre-service middle school math teachers' views about using technology in their lessons were also thematized as positive and negative opinions. In addition to the above, under the theme of positive opinions, participants indicated that technology makes lessons more enjoyable, saves time by freeing teachers from the situations like drawing shapes, facilitates the teachers' work, and gives students the opportunity to reach the information whenever and wherever they want. Some of the views that exemplified this theme best are as follows: 
M4: "Technology should definitely be used in math. Traditional teaching techniques are both boring for students and time-consuming. Since mathematics is abstract and difficult, we should use technology to provide permanent learning, to make teaching enjoyable and visual, to free teacher from drawing shapes, to make videos about the subject, to evaluate the subject using enjoyable tests on a computer."

M9: "Embodying the learning of our students, who are at the formal operational stage yet, makes learning easier and provides permanent learning. Also, it endears math, it makes this course enjoyable."

However, regarding the negative opinions theme, the participants thought that the use of technology in math is not suitable for every subject of mathematics, and technology cannot be used at every stage of the course. Participants also stated that using tablet computer is not ideal since it has some drawbacks such as playing games or surfing on the Internet, using technology may cause health problems such as eye diseases and postural problems, and it is uneconomic. Furthermore, the participants emphasized once more that paper and pencil are irreplaceable in teaching math. Being one of the participants who think in such way, M7 expressed his / her views as follows:

M7: "Although there are many good sides of technology, there are also some bad sides. For example, a teacher who does not know how to use a computer causes the educational institution to fritter away the budget of technology. Or looking at the screen constantly may disrupt students' eyes. It distracts attention. In rural areas, perhaps even in other places, every school may not have equal conditions, and the budget may be inadequate."

\subsection{Thoughts on Presentation Programs in Science/Middle School Math Courses}

The participants' thoughts about using presentation programs in their lessons are generally as these programs make course interesting and enjoyable, visualize the topic, make learning easier, and helps to enable the permanent learning (Figure 4). Therefore, thoughts of pre-service science teacher S3 and pre-service math teacher M5, two of the participants who exemplified the theme named 'positive opinions about using presentation programs' best, were given below, respectively:

"Presentation programs make the lesson enjoyable. They visualize the course subjects. This is why they provide permanent learning."

"These programs make students understand the lesson better. It makes the course more interesting and visual since the visuals can be used. Students can learn easily."

On the other hand, pre-service science teachers also mentioned that there are some problems regarding using PowerPoint in the lessons. These views of the participants were thematized as negative opinions. Accordingly, pre-service science teachers thought that preparing a presentation may be time-consuming for the teacher; it may also become boring if it is used throughout the course, and classroom management will be difficult. S9, who thought so, said that:

"It would be nice if presentation programs are used properly. However, there are buts about it... Now, the presentation is being constantly used in our lessons and we are obviously getting bored. Because teachers always use the presentation, not the time when it is needed. I am against to using presentation constantly in courses such as physics and chemistry. Can solving the question be in the presentation? If the students were already bored, they become distracted and you cannot gather the classroom."

Pre-service mathematics teachers also stated that the presentation programs have some negative features (Figure 4). These opinions which were grouped under the theme of negative opinions are; some of the presentation programs require Internet connection, the use of program is difficult when it is not in Turkish, the program is not useful for every subject in math, and preparing a presentation is time-consuming for teachers. The views of M7, who had the same opinion, were given below:

"These programs are not very suitable for mathematics. Moreover, it is never suitable for every subject. And I think that it should never be used from the beginning to the end of the course. A short description of the topic may be made using these programs. Or perhaps a visual that is difficult to draw on the board may be shown. I also think that the programs that require Internet connection are also negative. What if there is no Internet connection while making a presentation?" 


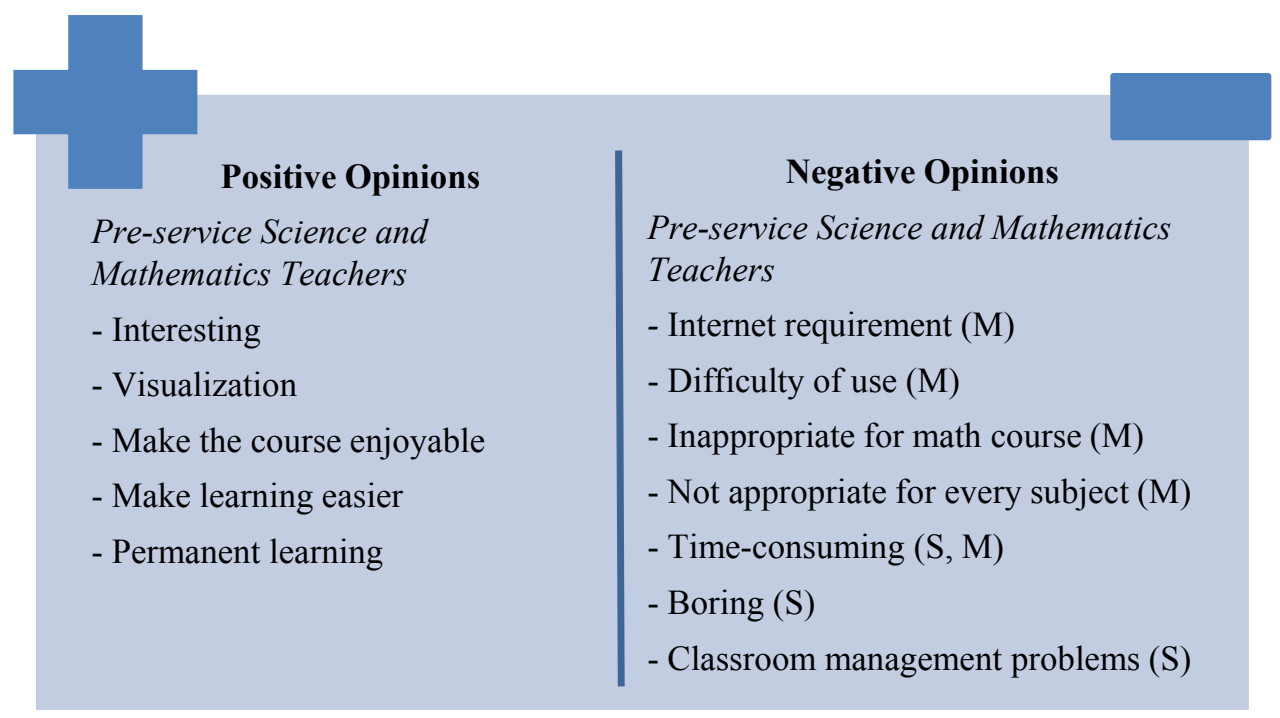

Figure 4. Opinions about using presentation programs in science/math courses

\subsection{Thoughts on Using Blog or Web Page in Science/Middle School Math Courses}

The participants' opinions on the use of blogs or web pages in their lessons are generally relevant to some opportunities that these applications give such as; to share the course content and materials, to make announcements to make students prepared for the course, and to share information. The opinions of both pre-service teachers were gathered under the theme of positive opinions (Figure 5).

Other than above-mentioned views, pre-service science teachers' views about the theme of positive opinions are; it is possible to share information about science and daily life using blog or web page in the science course; blog and web page develop students' writing skills, provide permanent learning, and give students who cannot ask question or learn the subject the opportunity to learn. S11, who thinks so stated that:

"Due to the blogs, a student who did not understand the lesson but wants to make research can reach the information. Or, for example, if you want students come to class prepared as a teacher, you can make an announcement through these applications and present the course content to the students. Also, it is possible to communicate and share the topic with other people."

As well as their previously mentioned opinions, pre-service math teachers also stated that blog and web page applications improve students' research skills and these applications are remarkable since they are out of the ordinary. M15, who expressed his / her opinion in this way, stated that:

"Blogs or web pages may be useful in transferring thoughts and opinions about teaching math or mathematics itself. Since it will bring visual elements into the forefront, permanence increases. The research skills develop while searching within blogs."

On the other side, pre-service science teachers mentioned that blogs or web pages have a negative side such as the Internet requirement (Figure 5). For instance, S14, who defends this opinion, said that "The answer for the question 'Do the blogs work?' 'is definitely 'yes'. But we absolutely should enter through the Internet. How many students will have this opportunity at a village school? It may cause distress from this aspect."

Similarly, some pre-service math teachers expressed their opinion as these applications are more suitable for lessons with verbal content or sharing about daily life. M8 expressed his/her thoughts as "Although these applications are useful for mathematics, they can be used in a limited way. Because the blog seems to be an internet tool that is based on more up to date things. However, if you will make an announcement, for example, you can still use it." 


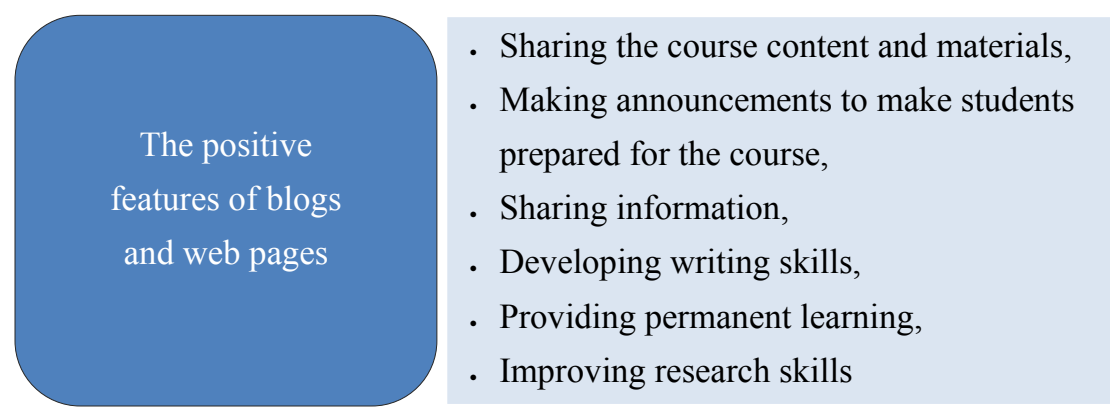

- Sharing the course content and materials,

Making announcements to make students prepared for the course,

features of blogs

- Sharing information,

- Developing writing skills,

- Providing permanent learning,

- Improving research skills

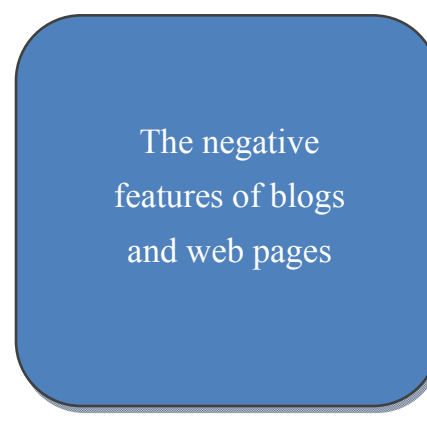

- Internet requirement

- More suitable for lessons with verbal content or sharing about daily life

Figure 5. Pre-service science/middle school math teachers' thoughts about using blogs and web pages

\subsection{Thoughts on Using Video Processing Programs in Science/Middle School Math Courses}

Both pre-service science and math teachers have similar opinions about using video processing programs in their lessons (Figure 6). Participants mentioned the positive features of video processing programs and therefore created positive contacts. Since the participants mentioned the positive features of video processing programs, a theme named 'positive opinions' was formed. This theme includes the participants' thoughts such as video processing programs can be used in preparing course content presentations; video processing programs are interesting, they provide permanent learning, visualize the lesson, and make the course enjoyable. Different from those, pre-service middle school math teachers also stated that it is possible to be beneficial to students by making a question solving video with these programs and to study by watching the videos whenever and wherever they want. The thoughts of pre-service science teacher S4 and pre-service math teacher M2, who exemplified this theme best, as follows, respectively:

"Owing to these programs, interesting and visual videos can be made. A video about the topic content can be generated. I think the lesson becomes enjoyable and the learning becomes permanent."

"In general, a video is created by adding pictures, text, and effects with some programs. Short videos can be created and added for solving questions in mathematics. The teacher can make a comprehensive video, lecture on the topic, and then give it to the students. Thus, thanks to computer and telephone, students can study the topic again in their out of school time. The learning becomes permanent." 


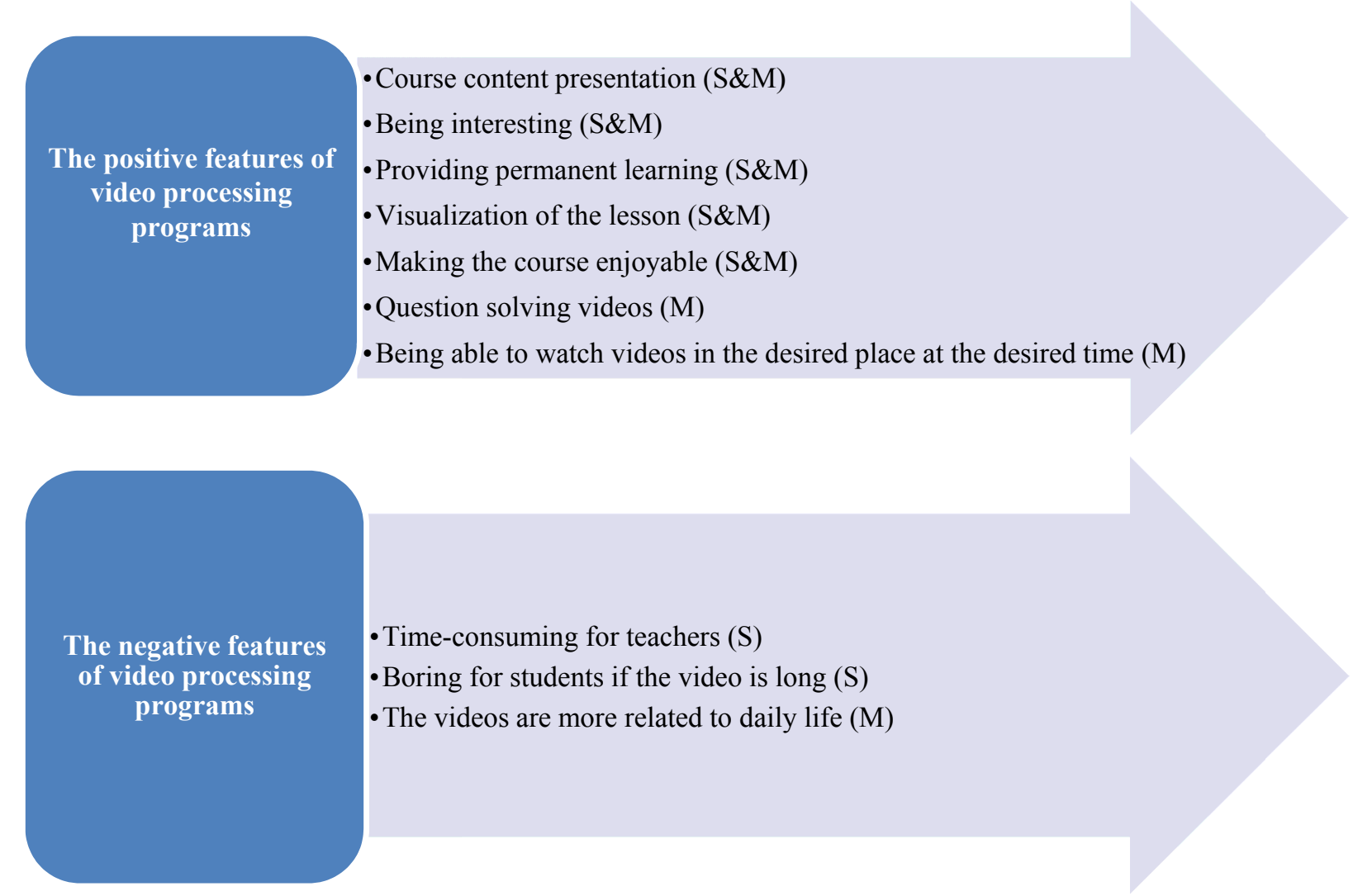

Figure 6. Pre-service science/middle school math teachers' thoughts about using video processing programs in their courses

Nevertheless, pre-service science teachers believed that preparing a material using video processing programs is time-consuming for teachers and also it will be boring for students if the video is long. In this regard, S15 stated that:

“...But it is very time-consuming to prepare them, it takes a lot of time. In fact, it is more appropriate to use short video, students already get bored in the long videos. Also, a short video does not waste teacher's time."

Pre-service math teachers stated that the videos are more related to daily life situations rather than mathematics lesson, hence it is more appropriate to rarely use it in math. Thinking in that way, M10 said:

"I personally think that the videos are not so useful for math, it is more useful for daily life. Then, is it unusable? No, it is also used in math. But how? For example, at Pi Day event, on the topic of history of math... But there is no doubt that you cannot use it in a geometry class."

\subsection{Thoughts on Teaching in Technologically Fully-equipped or Ill-equipped Classrooms}

Accept three participants, all of the pre-service science and math teachers stated that the technological equipment that their classroom has definitely affects their teaching. They explained this situation through students' cognitive and affective learning domains in general. In other words, the obtained data were thematized in this way.

In the theme of cognitive learning domain, both pre-service science and mathematics teachers stated that if they do not have the technological equipment in their classrooms; the students would have difficulty in learning, their learning would not be permanent, and the students would tend to memorize things. Pre-service science teacher S8 and pre-service middle school math teacher M8 expressed their opinions regarding this theme as follows:

"If a classroom is non or ill-equipped with technology, it is like doing a cancer surgery in health center rather than in a general hospital. Of course, it affects teaching. It affects students'learning mostly. Science can not be learned only by transferring it from the blackboard to the notebook. The basis of science is practicing; if students practice, permanent learning occurs. This can only be done in a technologically equipped classroom."

"It may not differ much according to the teacher. But it changes a lot for students. What actually changes? Mostly the students can no longer learn easily. When technology is not used, even if presentation strategy is used, 
the students would tend to memorize the knowledge."

In the theme of affective cognitive domain, both pre-service science and mathematics teachers stated that if there is a lack of the technological equipment in their classrooms; it affects the students' attitudes, interests, and motivations towards the course; enjoyment in the lesson, learning entertainingly, and participation in the lesson. The views of the pre-service science and math teachers who thought in that way were given below:

S9: "If the classroom is technologically ill-equipped, it will definitely be different. The students will löse their interest in the course. They cannot learn by having fun, learning will not be permanent."

M1: "Math is a course that is entwined with technology. Thus, classrooms should be fully-equipped with technology. Otherwise, students' motivation towards lesson will decrease, their attention will be distracted, the lesson will become boring. Success will decrease. The prejudice against math already exists; if this increases, a negative attitude towards the course may be developed."

In addition, the participants who defend the opinion that technological equipment of their classrooms will not affect their teaching justified their opinion as science can also be taught using different materials other than technology and teacher is the most important element of teaching. For instance, while pre-service science teacher S10 expressed his/her thoughts as "I do not think it affects. Because everything around us in the daily life is a learning material for science. For this reason, there is no need to technology to tell science.", pre-service math teacher M15 expressed his/her thoughts on the topic as "I think this will not affect the lesson at all. To me, the teacher is the most important factor that affects the quality of science teaching. There are many teachers who teach inefficiently at fully-equipped schools, but do miracles at ill-equipped schools."

\section{Findings, Discussion, and Suggestions}

In this research, that was conducted to determine the opinions of pre-service teachers about the use of technology in science and middle school mathematics lessons, it was thought that pre-service teachers' positive and negative views about the use of technology in education may affect their educational pedagogies and practices in the future.

The findings of the study indicated that according to the pre-service science teachers, smart boards, laboratory equipment, computer, and projector are the foremost technologies that can be used in their lessons. According to the pre-service math teachers, on the other hand, computer, smart board, notebook, and pencil are the foremost technologies that can be used in their lessons. Hence, it can be stated that pre-service science teachers focus on using electronic devices in their lessons, but pre-service mathematics teachers also pay attention to the non-electronic devices such as notebook and pencil. According to the pre-service math teachers, the requirements for math course like writing and drawing make the use of notebook and pencil indispensable. In parallel with this result, in the study conducted by Önal (2014), it was found that math teachers frequently use the electronic devices such as a computer, projector, and smartboard in their lessons. On the other hand, different from the present study, in the study of Önal (2014), it was also pointed out that math teachers frequently use the non-electronic equipment -blackboard, 3D materials, and fraction cards in their courses. The possible reason why participants frequently use electronic devices like smartboard, computer, and projector may be the common usage of mentioned technologies. Consistent with these findings, Baki et al. (2009) also pointed out that the most common educational technology used by teachers is the computer. However, the study conducted by Yangin and Kaya (2016) aimed to determine the tools used in teaching "The Systems in Our Body" unit in science course, and concluded that teachers frequently used written materials other than textbook and blackboard, but did not use the technologies such as smartboard and projector.

Another finding of this study shows that the participants thought the use of technology in education facilitates students' learning, provides permanent learning, embodies abstract subjects, saves time and arouses students' interest and curiosity. Similarly, Woodard (2003) stated that using technology in education provides access to different kinds of information sources, allows different kinds of learning, enhances motivation, and enables students to take part in the learning process; while Shumack and Reilly (2011) mentioned that using technology in education gives students the opportunity to obtain information in the way, place and at the time they wish. Based on İnal, Evrekli, and Balım's (2011) study, pre-service science teachers believed that the use of educational technologies in lessons supports students' visual and auditory learning, enhances interest and attention, facilitates learning, provides permanent learning, and helps to embody the abstract concepts. Not limited to this, many studies have shown that educational stakeholders have positive views on the use of technology in education (Amelink \& Scales, 2010; Carvalho-Knighton \& Keen-Rocha, 2007; Cüre \& Özdener, 2008; Çăğltay et al., 2007; Yılmaz, Ulucan, \& Pehlivan, 2010).

On the other hand, according to the participants, the use of technology in education has some limitations such as 
inadequacy of physical resources, interruption of the course in case of power failure, the necessity of teachers having the ability to use technology; also technology use may lead to some health problems, and distractibility, and it may not be suitable to teach every subject. Lane and Lyle (2011), who laid emphasis on teachers' technological skills, also stated that technical expertise is important for using educational technologies in the courses. Moreover, it has become a necessity for teachers to have the abilities to use educational technologies as they are faced with a group of learners who use technological tools such as computers, Internet, and mobile devices intensively (Reiner, 2009). In their study, İnal, Evrekli, and Balım (2011) stated that pre-service science teachers were in the opinion that educational technologies are partially appropriate for every science topic.

The participants in the study detailed their views on technology applications that can be used in education within the context of presentation programs, video processing programs, and blog or web page usage. In this regard, it was found that the participants believed using presentation programs in lessons has some positive effects such as making the lesson fun and interesting, visualizing the subject, facilitating learning, and helping to provide permanent learning. These results, which are likely to affect pre-service teachers' teaching performance during their teaching profession, may be due to that presentations are often used at every stage of the education. Consistent with these results, it is recommended that teachers use Microsoft PowerPoint presentation program due to its features such as transferring information to a crowded group, facilitating learning by appealing to multiple senses (Jenq, Yen, \& Pao, 2007). Likewise, it was found that presentations improved teaching and organizational skills (Susskind, 2005), enhanced the positive attitude towards the lesson (Tabuk, 2003), increased students' motivation (Selimoğlu, Arsoy, \& Ertan, 2009) and willingness to participate in the lessons made with the presentation (Szabo \& Hastings, 2000).

Another consequence of this research is that the pre-service science teachers thought preparation of a presentation may be time-consuming for teachers, it may become boring if the presentation is used throughout the lesson, and the classroom management may be difficult. Additionally, pre-service math teachers also stated that presentation programs have some negative features-some of the presentation programs require Internet, and when the program is not in Turkish, it is difficult to use, it is not suitable for math or every topic of math, and it is time consuming for teachers to prepare presentations. These thoughts among the participants may be due to prejudices of in-service and pre-service teachers regarding the integration of technology in education, or teachers' willingness to avoidance of spending time on pre-class preparations. In parallel with these findings, it was also reported in the related literature that a major part of teachers described the preparations for the integration of technology into teaching as boring and time-consuming (Christanse, 2002; Levin, 1996).

Another conclusion reached in this study is that the participants indicated the positive features of using blog or web page in their lessons as they give students an opportunity to share course content and materials and make announcements to help students come to class prepared. These views of participants may result from social networks such as blogs or web pages are often used for these purposes in Turkey. In support of this, Jones, Blackey, Fitzgibbon and Chew (2010) suggested that the use of social networks in education is flexible, it facilitates building a community and sharing, enhances communication, and makes it easier to give feedback. Ajjan and Hartshorne (2008) stated that just as blogs, social networks also strengthen the communication among users, provide sharing opportunities and improve the cooperation. Moreover, pre-service science teachers mentioned that using blog or web pages improves writing skills of students, provides permanent learning, makes students share about science and daily life and gives learning opportunity to the students who cannot ask questions or learn the subject. Pre-service math teachers stated that blog or web pages improve research skills of students, and these applications are remarkable since they are unconventional. However, according to the participants, there are some negative aspects of using blogs or web pages in their lessons. At this point, while pre-service science teachers thought that using a blog or web page require an Internet connection, pre-service math teachers found these applications more suitable for verbal lessons or sharing about daily life.

Yet another conclusion reached in this study is that participants thought video processing programs have some positive features, for instance, they present the course content, provide permanent learning, visualize the course, make the course enjoyable, and they are interesting. In addition to this, pre-service middle school math teachers thought that with these programs, it is possible to be beneficial to students by preparing question-solving videos and to study a subject by watching the videos at the desired place and time. Concordantly, according to Shumack and Reilly (2011), podcasting technology can complement, change, diversify, and possibly improve the way that information is presented in the classroom. Because this technology facilitates the sharing of information, allows students to answer more questions, motivates students and improves their creativity. However, pre-service science teachers believe that preparing a material with video processing programs is time-consuming for teachers and it can be boring for students if the video is long. Pre-service math teachers stated that videos should rarely be used in 
math since they are more about daily life situations than math.

Lastly, the participants' views on teaching carried out in classrooms with or without technological equipment were examined. According to the participants, the technological equipment in their classroom definitely affect the teaching they will perform. In this regard, participants thought that if they do not have the technological equipment in their classroom; students will have difficulty in learning and turn towards memorization, and their learning will not be permanent. Also, students' learning motivation, attitudes and interests towards the course, their participation in the lesson, and their learning by having fun may be affected by this situation. Concordantly, Cohen, Manion, and Morrison (2010) suggested that the physical environment constructs the skeleton of learning, and it can contribute to learning or prevent learning. Additionally, according to some of the participants, there are many tools or materials that can be used in courses other than technology. Moreover, the teacher is the most effective element in teaching and therefore the technological equipment in their classroom do not affect their instruction.

According to the results of this research, the following recommendations can be offered:

- Pre-service teachers should be sufficiently informed about new technologies and be able to apply these new technologies in order not to be confined to the use of computer, projection and smart board.

- Pre-service teachers should be given practical training on how to use the applications such as presentations and video programs, blogs or web pages which are also subject to this research in general, in education, and in particular, in their own lessons; and how to eliminate the limitations of these applications.

- The weight and importance should be given to the courses in which the pre-service teachers have the necessary knowledge and skills about how and in what way the technological equipment will be used in their lessons. Instructors must motivate and adequately train pre-service teachers in these courses.

- Since this research is limited to the current study group only, the subject should be studied more thoroughly by repeating the study with pre-service teachers from different departments.

\section{References}

Ajjan, H., \& Hartshorne, R., (2008). Investigating faculty decisions to adopt web 2.0 technologies: Theory and empirical tests. Internet and Higher Education, 11(2), 71-80. https://doi.org/10.1016/j.iheduc.2008.05.002

Amelink, C. T., \& Scales, G. R. (2010). Student learning behaviours promoted with instructional technology. 40 th ASEE/IEEE Frontiers in Education Conference, Arlington, United States.

Baki, A., Aydın-Yalçınkaya, H., Özpınar, İ., \& Çalık-Uzun, S. (2009). İlköğretim matematik öğretmenleri ve öğretmen adaylarının öğretim teknolojilerine bakışlarının karşılaştırılması. Turkish Journal of Computer and Mathematics Education, 1(1), 65-85.

Baturay, M. H., Gökçearslan, Ş., \& Ke, F. (2017). The relationship among pre-service teachers' computer competence, attitude towards computer-assisted education, and intention of technology acceptance. International Journal of Technology Enhanced Learning, 9(1), 1-13. https://doi.org/10.1504/IJTEL.2017.084084

Çağıltay, K., Yıldırım, S., Arslan, İ., Gök, A., Gürel, G., Karakuş, T., ..., Yıldız, İ. (2007). Öğretim teknolojilerinin üniversitede kullanımına yönelik alışkanlıklar ve beklentiler: Betimleyici bir çalışma. Akademik Bilişim Konferansı, Dumlupınar Üniversitesi, Kütahya.

Carvalho-Knighton, K. M., \& Keen-Rocha L. (2007). Using technology to enhance the effectiveness of general chemistry laboratory courses. Journal of Chemical Education, 84(4), 727-730. https://doi.org/10.1021/ed084p727

Çelik, H., \& Karamustafaoğlu, O. (2016). Fen bilgisi öğretmen adaylarının fizik kavramları öğretiminde bilişim teknolojilerinin kullanımına yönelik öz-yeterlik ve görüşleri. Necatibey Eğitim Fakültesi Elektronik Fen ve Matematik Ë̆itimi Dergisi, 10(1), 182-208. https://doi.org/10.17522/nefefmed.95930

Christanse, R. (2002). Effects of technology integration education on the attitudes of teachers and students. Journal of Research on Technology in Education, 34(4), 411-434. https://doi.org/10.1080/15391523.2002.10782359

Ciampa, K. (2014). Learning in a mobile age: An investigation of student motivation. Journal of Computer Assisted Learning, 30(1), 82-96. https://doi.org/10.1111/jcal.12036

Cohen, L., Manion, L., \& Morrison, K. (2010). A guide to teaching practice (4th ed.). London and New York: Routledge. https://doi.org/10.4324/9780203848623 
Çoklar, A. N., \& Tercan, I. (2014). Opinions of teachers toward the use of smart boards. Elementary Education Online, 13(1), 48-61.

Cope, C., \& Ward, P. (2002). Integrating learning technology into classrooms: The importance of teachers' perceptions. Educational Technology \& Society, 5(1), 67-70.

Creswell, J. W. (2013). Research design. Thousand Oaks, CA: Sage.

Cüre, F., \& Özdener, N. (2008). Öğretmenlerin bilgi ve iletişim teknolojileri (BİT) uygulama başarıları ve BİT'e yönelik tutumları. Hacettepe Üniversitesi Eğitim Fakültesi Dergisi, 34, 41-53.

Daymon, C., \& Holloway, I. (2003). Qualitative Research Methods in Public Relations and marketing communications. London: Routledge.

Ertmer, P. A. (2005). Teacher pedagogical beliefs: The final frontier in our quest for technology integration? Educational Technology Researchand Development, 53(4), 25-39. https://doi.org/10.1007/BF02504683

Glesne C. (2011). Becoming qualitative researchers: An introduction (4th ed.). Boston, MA: Pearson.

Glesne, C. (2012). Nitel araştırmaya giriş (Çeviri Editörleri: Ali Ersoy \& Pelin Yalçınoğlu). Ankara: Anı Yayıncilik.

Gorder, L. M. (2008). A study of teacher perceptions of instructional technology integration in the classroom. The Delta Pi Epsilon Journal, 50(2), 63-76.

Hennessy, S. (2008). Integrating technology into teaching and learning of school science: A situated perspective on pedagogical 1ssues in research. Studies in Science Education, 42(1), 1-48. https://doi.org/10.1080/03057260608560219

İnel, D., Evrekli, E., \& Balım, A. G. (2011). Öğretmen adaylarının fen ve teknoloji dersinde eğitim teknolojilerinin kullanılmasına ilişkin görüşleri. Kuramsal Eğitimbilim, 4(2), 128-150.

Jenq, M. H., Yen S. L., \& Pao, T. Y. (2007). Using multimedia annotation tool for the instructional cues and explanations. 15th International Conference on Advanced Computing and Communications, India.

Jones, N., Blackey, H., Fitzgibbon, K., \& Chew, E. (2010). Get out of Myspace!. Computers \& Education, 54(3), 776-782. https://doi.org/10.1016/j.compedu.2009.07.008

Kağızmanlı, T. B., Tatar, E., \& Zengin, Y. (2013). Öğretmen adaylarının matematik öğretiminde teknoloji kullanımına ilişkin algılarının incelenmesi. Ahi Evran Üniversitesi Kırşehir Eğitim Fakültesi Dergisi, 14(2), 349-370.

Köksal, M. S., \& Yaman, S. (2012). Turkish prospective teachers' perceptions about technology in education. Gazi University Journal of Gazi Educational Faculty, 32(2), 221-237.

Lane, C. A., \& Lyle, H. F. (2011). Obstacles and supports related to the use of educational technologies: The role of technological expertise, gender, and age. Journal of Computing in Higher Education, 23(1), 38-59. https://doi.org/10.1007/s12528-010-9034-3

Levin, B. B. (1996). Using portfolios to fulfill ISTE/NCATE technology requirements for preservice teacher candidates. Journal of Computing in Teacher Education, 12(3), 13-20.

Lewin, C., Somekh, B., \& Steadman, S. (2008). Embedding interactive whiteboards in teaching and learning: The process of change in pedagogic practice. Education and Information Technologies, 13(4), 291-303. https://doi.org/10.1007/s10639-008-9070-z

Mandell, S., Sorge, D. H., \& Russell, J. D. (2002). Tips for technology integration. TechTrends, 46(5), 39-43. https://doi.org/10.1007/BF02818307

Metin, M., Birişçi, S., \& Coşkun, K. (2013). Öğretmen adaylarının öğretim teknolojilerine yönelik tutumlarının farklı değişkenler açısından incelenmesi. Kastamonu Eğitim Dergisi, 21(4), 1345-1364.

Mettas, A. C., \& Constantinou, C. C. (2007). The technology fair: A project-based learning approach for enhancing problem solving skills and interest in design and technology education. International Journal of Technology and Design Education, 18(1), 79-100. https://doi.org/10.1007/s10798-006-9011-3

Önal, N. (2014). Ortaokul matematik öğretmenlerinin bilişim teknolojileri yeterliliklerine ilişskin görüşleri (Yayımlanmış Doktora Tezi). Gazi Üniversitesi Eğitim Bilimleri Enstitüsü, Ankara.

Özden, M. Y., Çağıltay, K., \& Çağıltay, E. (2004). Teknoloji ve eğitim: Ülke deneyimleri ve Türkiye için dersler. İstanbul: 76-93. 
Patton, M. Q. (2002). Qualitative evaluation and research methods (3rd ed.). Thousand Oaks, CA: Sage Publication.

Reiner, M. (2009). Sensory cues, visualization and physics learning. International Journal of Science Education, 31(3), 343-364. https://doi.org/10.1080/09500690802595789

Roblyer, M., \& Edwards, J. (2005). Integrating educational technology into teaching (4th ed.) Upper Saddler River, NJ: Prentice-Hall.

Saraç, H., \& Özarslan, M. (2017). Fen alanı öğretmen adaylarının bilgi ve iletişim teknolojilerine yönelik görüşleri. International e-Journal of Educational Studies, 1(1), 32-46.

Selimoğlu, S. K., Arsoy, A. P., \& Ertan, Y. (2009). The effect of powerpoint preferences of students on their performance: A research in Anadolu University. Turkish Online Journal Of Distance Education-Tojde, 10(1), 114-129.

Shumack, K. A., \& Reilly, E. (2011). Video podcasting in physical education. Journal of Physical Education, Recreation \& Dance, 82(1), 39-43. https://doi.org/10.1080/07303084.2011.10598560

Som, İ. (2017). Öğretmen adaylarının öğretim amaçlı bilişim teknolojileri kullanımına ilişkin görüşlerinin incelenmesi. International Journal of Social Sciences and Education Research, 3(3), 882-898. https://doi.org/10.24289/ijsser.311186

Susskind, J. E. (2005). PowerPoint's power in the classroom: Enhancing students' self-efficacy and attitudes. Computers \& Education, 45, 203-215. https://doi.org/10.1016/j.compedu.2004.07.005

Szabo, A., \& Hastings, N., (2000). Using IT in the undergraduate classroom: Should we replace the blackboard with PowerPoint? Computers \& Education, 35, 175-187. https://doi.org/10.1016/S0360-1315(00)00030-0

Teo, T. (2008). A path analysis of pre-service teachers' attitudes to computer use: Applying and extending the technology acceptance model in an educational context. Interactive Learning Environments, 1-15.

Van Manen, M. (2007). Phenomenology of practice. Phenomenology \& Practice, 1(1), 11-30.

Woodard, B. S. (2003). Technology and the constructivist learning environment: implications for teaching information literacy skills. Research Strategies, 19(3-4), 181-192. https://doi.org/10.1016/j.resstr.2005.01.001

Yangın, S., \& Kaya, D. R. (2016). Fen ve teknoloji dersinde kullanılan araç-gereçler ve öğretim yöntemleri: Öğretmen ve öğrenci görüşleri. Journal of Research in Education and Teaching, 5(1), 29-42.

Yıldırım, A., \& Şimşek, H. (2008). Sosyal bilimlerde nitel araştırma yöntemleri (5. Baskı). Ankara: Seçkin Yayıncilik.

Yılmaz, İ., Ulucan, H., \& Pehlivan, S. (2010). Beden eğitimi öğretmenliği programında öğrenim gören öğrencilerin eğitimde teknoloji kullanımına ilişkin tutum ve düşünceleri. Ahi Evran Üniversitesi Eğitim Fakültesi Dergisi, 11(1), 105-118.

Yüksel-Arslan, P., Şad, S. N., \& Yıldırım, S. (2017). Motivational and ethical ıssues in seamless learning: Use of tablet PCs in a mobile and ubiquitous technology-enhanced learning context. In S. N. Şad, \& M. Ebner (Eds.), Digital tools for seamless learning (pp. 240-254). IGI Global Publications. https://doi.org/10.4018/978-1-5225-1692-7.ch012

Zhao, Y., Hueyshan, T., \& Mishra, P. (2001). Technology: Teaching and learning: Whose computer is it? Journal of Adolescent and Adult Literacy, 44, 348-355.

\section{Copyrights}

Copyright for this article is retained by the author(s), with first publication rights granted to the journal.

This is an open-access article distributed under the terms and conditions of the Creative Commons Attribution license (http://creativecommons.org/licenses/by/4.0/). 